\title{
Percepcja informacji żywieniowej jako elementu wpływającego na zachowania konsumentów w zakładach gastronomicznych
}

\section{Wstęp}

Zachowania konsumentów na rynku usług gastronomicznych determinowane są różnorodnymi czynnikami o charakterze społecznym, ekonomicznym, kulturowym, psychologicznym i demograficznym. Wpływają one na wybór zakładu gastronomicznego i konkretnej pozycji z menu, stanowiąc jednocześnie czynnik determinujący percepcję przekazywanej informacji. Ważnym obszarem informacyjnym w zakładach gastronomicznych jest informacja żywieniowa odnosząca się do wartości odżywczej i składu produktowego.

Celem niniejszego opracowania była ocena percepcji informacji żywieniowej przekazywanej przez personel pierwszego kontaktu jako element wpływający na zachowania konsumentów w zakładach gastronomicznych. Jako przykład przyjęto korporację McDonald's, wskazując na powszechność dostępnych usług, popularność tych placówek oraz rolę personelu pierwszego kontaktu przekazującego informację żywieniową.

\section{Materiał i metodyka}

Dla realizacji tak postawionego celu przeprowadzono w czerwcu 2016 roku badanie ilościowe na próbie 403 osób z wykorzystaniem doboru celowego. Przyjęto kryteria wieku (od 18 do 35 lat), zamieszkiwanie w dużych miastach oraz fakt korzystania z usług lokali gastronomicznych. Kryterium wieku odnosi się 


\section{4}

do zdefiniowania grupy młodych konsumentów. Do grupy badawczej zakwalifikowano osoby, które w ciągu 3 ostatnich miesięcy skorzystały z usług lokali gastronomicznych. Badanie zrealizowano metodą CAWI. Badania przeprowadzono w ramach projektu naukowo-edukacyjnego „Konsument na rynku usług gastronomicznych", nr 507-30-102-M00094-99, porozumienie o współpracy nr CIiTT/83/2014.

W strukturze badanej populacji, kobiety i mężczyźni stanowili prawie równo liczne grupy. Ponad 50\% respondentów korzystało z usług lokali gastronomicznych przynajmniej raz w tygodniu, mężczyźni deklarowali częstsze korzystanie z tych usług w porównaniu do kobiet. Średni wiek kobiet był niższy od średniego wieku mężczyzn biorących udział w badaniu, a przeciętny wiek respondentów wynosił 28 lat. Wykształcenie wyższe zadeklarowała prawie połowa respondentów (tab. 1).

\section{Tabela 1}

Charakterystyka badanej populacji

\begin{tabular}{|c|c|c|c|}
\hline Wyszczególnienie & Ogółem & Kobiety & Mężczyźni \\
\hline Płeć [\%] & 100 & 50,87 & 49,13 \\
\hline \multicolumn{4}{|c|}{ Częstotliwość korzystania z usług gastronomicznych [\%] } \\
\hline Raz w tygodniu i częściej & 52,35 & 46,83 & 58,08 \\
\hline 2-3 razy w miesiącu & 27,30 & 28,29 & 26,26 \\
\hline Raz w miesiącu & 13,65 & 16,10 & 11,11 \\
\hline Raz na 3 miesiące & 6,70 & 8,78 & 4,55 \\
\hline Wiek [lata] & 28 & 27 & 29 \\
\hline \multicolumn{4}{|c|}{ Wykształcenie [\%] } \\
\hline Podstawowe, zawodowe, średnie & 51,12 & 54,15 & 47,98 \\
\hline Wyższe & 48,88 & 45,85 & 52,02 \\
\hline
\end{tabular}

$\mathrm{N}=403$

Źródło: Badania własne.

Badanie przeprowadzono na podstawie autorskiego kwestionariusza ankiety składającego się z części merytorycznej oraz metryczki zawierającej pytania dotyczące: roku urodzenia, płci, wykształcenia, miejsca zamieszkania, liczby dzieci w gospodarstwie domowym. Zastosowano pytanie filtrujące dotyczące częstotliwości korzystania z usług gastronomicznych.

W niniejszym opracowaniu przeanalizowano zachowania konsumenckie, wybierając jedną z determinant wpływających na proces podejmowania decyzji. Jest to czynnik społeczny wyszczególniony jako wywieranie wpływu na konsumenta w kontaktach bezpośrednich. Analizy dokonano, bazując na opiniach dotyczących roli percepcji informacji żywieniowej przekazywanej przez personel 
pierwszego kontaktu restauracji McDonald's w podejmowaniu decyzji zakupowej, ocenie jej wiarygodności w kontekście różnych uwarunkowań oraz opisując wpływ poszczególnych cech wyglądu personelu restauracji McDonald's na wiarygodność przekazywanej informacji żywieniowej.

W części merytorycznej kwestionariusza dotyczącej znaczenia informacji żywieniowej w podejmowaniu decyzji zakupu oraz roli personelu pierwszego kontaktu w tym procesie zastosowano 5-stopniową skalę Likerta, gdzie 1 oznaczało zdecydowanie się nie zgadzam, 2 - raczej nie zgadzam się, 3 - ani się zgadzam, ani nie zgadzam, 4 - raczej się zgadzam, a 5 - zdecydowanie się zgadzam. $\mathrm{W}$ artykule przedstawiono wyniki dotyczące części pytań odnośnie stosunku respondentów do informacji żywieniowej udostępnianej w lokalu gastronomicznym, grupując stwierdzenia odnoszące się do rzeczywistej sytuacji oraz pokazujące otwartość respondentów na zmiany odnośnie korzystania z usług restauracji McDonald's.

W badaniu zastosowano dyferencjał semantyczny dla określenia stopnia, w jakim dana cecha personelu restauracji wpływa na wiarygodność udzielanej przez niego informacji żywieniowej. Respondenci prezentowali intensywność opinii wobec każdego zestawu przeciwstawnych cech przez zaznaczenie odpowiedzi jako punktu na skali bez wartości, któremu w dalszej analizie nadawano cyfrę od 1 do 6 . Odpowiedzi dla całej grupy uśredniono i ustalono, że wyniki mieszczące się $\mathrm{w}$ przedziale od 3 do 4 wskazują na obojętną postawę wobec danej cechy.

Uzyskane w badaniu dane poddano analizie pod względem płci oraz faktu posiadania dzieci. Dla uzyskanych wyników przeprowadzono test różnic dla analiz nieparametrycznych dla dwóch grup niezależnych U Manna-Whitneya, przyjmując przedział ufności na poziomie $95 \%(\mathrm{P}<0,05)$.

\section{Zachowania konsumentów a obsługa klienta - wybrane aspekty literatury}

Zachowanie konsumentów na rynku obejmuje obszerną przestrzeń analityczną i deskrypcyjną odnoszącą się do badań procesu decyzyjnego konsumentów [Gajewski 1997, Kramer 1997, Mazurek-Łopacińska 2003, Gutkowska i Ozimek 2005, Jachnis 2007]. W literaturze przedmiotu cytowanych jest wiele definicji, przykładowo wymienić należy określenie wskazujące na „ogół działań związanych z uzyskiwaniem i użytkowaniem produktów i usług oraz dysponowaniem nimi, wraz z decyzjami poprzedzającymi i warunkującymi te działania" [Engel, Blackwell i Miniard 1993, za Rudnicki 2012, s. 14]. Inna definicja podkreśla „ogół działań i percepcji konsumenta składających się na przygotowanie 
decyzji wyboru produktu, dokonanie owego wyboru oraz konsumowanie" [Hansen 1972, za Rudnicki 2012, s. 14].

Dla potrzeb niniejszego opracowania należy wskazać na zachowania konsumenckie rozpatrywane jako sposób hierarchizowania swoich potrzeb, wyboru oraz użytkowania dóbr i usług [Pohorille 1980]. Analogiczne postrzeganie zagadnienia zachowań konsumenckich odnaleźć można w kolejnej definicji, rozszerzając pierwszy etap odnoszący się do określenia potrzeb oraz ich oceny w przyznawaniu pierwszeństwa [Szczepański 1976].

Zachowania konsumpcyjne dokonywane są na rynku i w gospodarstwach domowych. Ogniskują się na pozyskaniu środków pieniężnych, a następnie na zachowaniach rynkowych, czyli nabywczych, m.in. zachowaniach bezpośrednio konsumpcyjnych [Kramer 1997]. Odnoszą się do procesu wyboru, nabywania i użytkowania stanowiącego część zasadniczą konsumpcji. Wiedza o konsumencie i jego zachowaniach jest niezbędna do zaplanowania i zrealizowania efektywnego programu działania każdego przedsiębiorstwa na rynku, umożliwiając przedsiębiorstwom wpływanie na wybory konsumenta [Rudnicki 2012].

Przedstawione w literaturze przedmiotu modele zachowań rynkowych konsumentów rozpatrywać należy jako uproszczenie rzeczywistości odzwierciedlające uwarunkowania decyzji konsumenckich [Rudnicki 2012, s. 17]. Spośród dostępnych modeli zachowań konsumentów na rynku żywności szczególnie istotne wydają się być modele Howarda-Shetha i Engla oraz Blackwella i Kollata.

Zachowania konsumentów w sferze żywności i żywienia stanowią szczególny rodzaj zachowań konsumenckich. Zachowania żywieniowe związane są z pozyskiwaniem żywności, jej doborem i sposobem zagospodarowania. Istotne jest również planowanie i przygotowanie posiłków, częstotliwość ich spożywania i kwestie odnoszące się do jakości żywności [Gutkowska i Ozimek 2005, s. 21].

Dokonując klasyfikacji zachowań konsumenckich w sferze żywności i żywienia, można przyjąć dwa kryteria (rys.):

1. Ujęcie przedmiotowe, wyodrębniające żywność ogółem i poszczególne kategorie produktowe.

2. Ujęcie podmiotowe, analizujące konsumentów ogółem i grupy konsumentów.

W realizacji celu niniejszego opracowania należy przyjąć, że analizowany obszar zachowań konsumenckich jest trzecim typem zachowań konsumentów odzwierciedlających określoną kategorię produktową (w tym przypadku żywienie w zakładach gastronomicznych) i grupę konsumentów ogółem.

Na zachowania konsumentów wpływa wiele czynników, a determinanty zachowań konsumentów można przedstawić za pomocą różnych klasyfikacji. Jedna z klasyfikacji obejmuje podział na determinanty wewnętrzne (psychologiczne i personalno-demograficzne) oraz zewnętrzne (społeczno-kulturowe i ekono- 
Ujęcie przedmiotowe

\begin{tabular}{|c|c|c|}
\hline \multirow{3}{*}{$\begin{array}{r}\text { Konsumenci } \\
\text { ogółem }\end{array}$} & Żywność ogółem & $\begin{array}{c}\text { Kategorie produktowe lub rodzaj } \\
\text { żywności }\end{array}$ \\
\hline & $\begin{array}{c}\text { I - zachowania konsumentów } \\
\text { ogółem w sferze żywności i żywienia }\end{array}$ & $\begin{array}{c}\text { III - zachowania } \\
\text { konsumentów ogółem w zakresie } \\
\text { wybranej kategorii produktowej } \\
\text { (np. zachowania konsumentów } \\
\text { w zakresie słodyczy) }\end{array}$ \\
\hline & $\begin{array}{l}\text { II - zachowania konsumenckie } \\
\text { w sferze żywności i żywienia } \\
\text { wybranych grup konsumentów } \\
\text { (np. zachowania młodzieży } \\
\text { w zakresie żywności i żywienia) }\end{array}$ & $\begin{array}{c}\text { IV - zachowania } \\
\text { konsumentów z wybranej grupy } \\
\text { w zakresie określonej kategorii } \\
\text { produktowej } \\
\text { (np. zachowania młodzieży } \\
\text { w zakresie słodyczy) }\end{array}$ \\
\hline
\end{tabular}

\section{Rysunek}

Macierz zachowań konsumenckich

Źródło: Górska-Warsewicz [2013, s. 71].

miczne). Obszar czynników psychologicznych odnosi się do motywów, emocji, osobowości, procesu uczenia się, postrzegania, postaw, etnocentryzmu i ryzyka, z kolei w obrębie uwarunkowań o charakterze personalno-demograficznych wskazać należy na wiek, płeć, fazę cyklu życia rodzinnego, wykształcenie, dochody i styl życia. Podobnego rozróżnienia dokonać można w przypadku czynników społeczno-kulturowych identyfikując rodzinę, grupę społeczną, grupę odniesienia, liderów opinii i kulturę oraz czynników ekonomicznych (produkt, ceny, miejsce sprzedaży, reklama oraz public relations) [Rudnicki 2012].

Inny podział determinant zachowań konsumentów identyfikuje trzy grupy: determinanty psychiczne (emocje, motywacje, przekonania, przeświadczenia, postawy), uwarunkowania społeczne (rodzina, grupy odniesienia, uznanie społeczne, wpływy kulturowe, style życia, komunikacja masowa, oddziaływanie reklamy i wywieranie wpływu na konsumenta w kontaktach bezpośrednich) oraz determinanty ekonomiczne zewnętrzne (wielkość PKB na jednego mieszkańca, fundusz spożycia, ceny towarów i usług konsumpcyjnych) i wewnętrzne (dochody, sposób gospodarowania budżetem domowym) [Światowy 2006].

Z punktu widzenia autorów niniejszego opracowania istotne są uwarunkowania społeczne, a wśród nich wywieranie wpływu na konsumenta w kontaktach bezpośrednich. Ten obszar odnosi się do obsługi klienta w zakładach gastronomicznych.

W literaturze istnieją różne definicje obsługi klienta, koncentrujące się na wielu jej aspektach. Logistyczny charakter obsługi klienta oddaje definicja wskazująca na czynności niezbędne do przyjęcia zamówienia klienta, wytworzenia i niezawodnego dostarczenia przedmiotu zamówienia w uzgodnionym miejscu 
i czasie, stosownie do oczekiwań klienta, komunikowania się z klientem przed sprzedażą, w jej trakcie i po niej, fakturowania oraz działania zmierzające do naprawy błędów popełnionych na którymkolwiek etapie realizacji zamówienia [Payne 1997].

Obsługę klienta podzielić należy na trzy zależne fazy: przedtransakcyjną (działania mające na celu zbadanie preferencji odbiorców, określenie standardów i wyznaczenie polityki obsługi klienta), transakcyjną dotyczącą procesu realizacji zamówienia oraz potransakcyjną obejmującą pomiar zadowolenia klientów, obsługę posprzedażową i reklamacje [Kramarz 2014].

Elementem kluczowym w zarządzaniu relacjami z klientem w przedsiębiorstwie jest stworzenie strategii obsługi klienta. Podstawę skutecznego określenia strategii obsługi klienta stanowi informacja o klientach, konkurentach i otoczeniu. Informacje pozyskiwane są ze źródeł wewnętrznych (wiedza pracowników, dane o klientach) i zewnętrznych (aktualne i przyszłe zachowania klientów i konkurencji, tendencje rozwojowe branży i rynku) [Grabowska 2013].

\section{Percepcja informacji żywieniowej jako elementu zachowań konsumentów w restauracjach McDonald's}

Realizację celu niniejszego opracowania przeprowadzono na przykładzie restauracji McDonald's. Obecnie w Polsce działają 372 restauracje w ponad 150 miastach, a menu obejmuje ofertę podstawową oraz śniadania serwowane od poniedziałku do piątku do godziny 10:30, a w weekendy do godziny 11:00.

$\mathrm{W}$ procesie wyboru dokonywanym przez konsumentów istotną rolę odgrywa obsługa konsumenta $\mathrm{w}$ aspekcie komunikowania się z klientem, obejmującym m.in. przyjęcie zamówienia, udzielanie informacji na życzenie klienta i wskazanie odpowiedniej pozycji w menu. Przekazywane informacje odnoszą się do oferowanych potraw i napojów m.in. w kontekście cen, promocji, możliwości komponowania zestawów, stosowanych w daniach dodatków itp. Odrębnym obszarem informacji jest informacja żywieniowa.

Przekazywanie informacji żywieniowej przez personel jest z jednej strony elementem obsługi konsumentów i procesu podejmowania decyzji wyboru, stanowiąc część zachowań konsumentów, a z drugiej ważnym elementem składającym się na proces zarządzania zasobami ludzkimi w korporacji z punktu widzenia struktury przedsiębiorstwa. Dotyczy to tzw. personelu pierwszego kontaktu i wpisuje się w uwarunkowania społeczne zachowań konsumentów. Należy zaznaczyć, że ścieżka kariery w korporacji McDonald's rozpoczyna się od zatrudnienia na stanowisku pracownika restauracji, czyli w ramach personelu pierwszego kontaktu. Do obowiązków pracowników zatrudnionych na tych 
stanowiskach pracy należy obsługa gości (przyjmowanie zamówień i obsługa kasy), przygotowywanie posiłków w kuchni lub praca na zapleczu. Taki sposób zatrudniania ma umożliwić pracownikom właściwe poznanie wszystkich aspektów funkcjonowania przedsiębiorstwa. Kolejnym etapem kariery zawodowej w McDonald's jest awans na stanowisko instruktora realizującego m.in. szkolenie pracowników mających krótszy staż pracy. Pracownicy restauracji mają również możliwość awansowania na stanowisko menedżera. W każdym lokalu pracuje od kilku do kilkunastu menedżerów zajmujących się koordynowaniem sprawnego działania poszczególnych obszarów restauracji. Najwyższe stanowiska to zastępca kierownika i kierownik restauracji.

Informacje o charakterze żywieniowym dostępne są również na stronie internetowej restauracji McDonald's, w aplikacji mobilnej McDonald's Polska i w lokalach. Są one przekazywane również przez personel w kontaktach bezpośrednich. Na stronie internetowej dostępne są częściowe informacje odnośnie rodzaju składników użytych do przygotowywania dań. Istnieje również możliwość pobrania ze strony tabeli alergenów i wartości odżywczych. W tabeli podane są informacje dotyczące obecności alergenów, wartości energetycznej (wyrażonej w kJ i kcal) i zawartości makroskładników: tłuszczów, kwasów. Funkcjonowanie aplikacji bazuje na zasadzie podobnej do działania strony internetowej restauracji.

Ocenę informacji żywieniowej i jej rolę w procesie dokonywania wyboru przeprowadzono przez zastosowanie określonych stwierdzeń, grupując je w dwie kategorie badawcze: oceny rzeczywistej sytuacji i otwartość respondentów na zmiany odnośnie korzystania z restauracji McDonald's.

W ocenie rzeczywistej sytuacji respondenci w najwyższym stopniu zgodzili się ze stwierdzeniami „Lubię, kiedy proces składania zamówienia w McDonald’s przebiega szybko i sprawnie” oraz „Proces składania zamówienia w McDonald's jest schematyczny i powtarzalny". Średnia dla odpowiedzi wyniosła odpowiednio 4,127 i 4,055. Średnią mieszczącą się w przedziale $(3,5 ; 4)$ zanotowano dla stwierdzenia w zakresie zainteresowania informacją żywieniową dotyczącą potraw w restauracjach McDonald's.

Opinie respondentów w zakresie ich otwartości na zmiany wykazywały największą zgodność dla stwierdzeń dotyczących wpływu znajomości wartości odżywczej na wybór dania oraz zmiany wyboru dania pod wpływem ewentualnej informacji żywieniowej udzielonej przez obsługę. Większość badanych wyrażała obojętne opinie odnoszące się do stwierdzeń w zakresie negatywnej oceny sytuacji, w której personel McDonald’s podczas składania zamówienia udziela klientowi informacji na temat wartości odżywczej wybranej potrawy.

Różnice średnich ocen w grupach respondentów mających dzieci i bezdzietnych nie były istotne statystyczne. $Z$ kolei płeć różnicowała istotnie statystycznie jedną opinię w obszarze oceny rzeczywistej sytuacji („Jestem zainteresowana/y 


\section{Tabela 2}

Zgodność opinii respondentów ze stwierdzeniami dotyczącymi restauracji McDonald's w zależności od posiadania przez nich dzieci

\begin{tabular}{|c|c|c|c|c|c|}
\hline Wyszczególnienie & Ogółem & Z dziećmi & Bez dzieci & $Z_{\text {pop }}{ }^{*}$ & $\mathrm{P}^{* *}$ \\
\hline \multicolumn{6}{|c|}{ Ocena rzeczywistej sytuacji } \\
\hline $\begin{array}{l}\text { Lubię kiedy proces składania zamówie- } \\
\text { nia w McDonald's przebiega szybko } \\
\text { i sprawnie }\end{array}$ & 4,13 & 4,10 & 4,16 & $-1,123$ & 0,262 \\
\hline $\begin{array}{l}\text { Proces składania zamówienia w McDo- } \\
\text { nald's jest schematyczny i powtarzalny }\end{array}$ & 4,06 & 4,02 & 4,10 & $-0,833$ & 0,404 \\
\hline $\begin{array}{l}\text { Jestem zainteresowana/y informacja } \\
\text { żywieniową dotycząca potraw w McDo- } \\
\text { nald's }\end{array}$ & 3,82 & 3,78 & 3,87 & $-1,128$ & 0,259 \\
\hline $\begin{array}{l}\text { Personel pierwszego kontaktu nie ma } \\
\text { wiedzy na temat wartości odżywczej } \\
\text { potraw oferowanych w McDonald's. }\end{array}$ & 3,57 & 3,63 & 3,51 & 1,255 & 0,209 \\
\hline $\begin{array}{l}\text { Nie lubię kiedy personel w McDonald's } \\
\text { udziela mi informacji niezwiązanych } \\
\text { z zamówieniem (np. promocje) }\end{array}$ & 3,357 & 3,36 & 3,35 & $-0,020$ & 0,984 \\
\hline \multicolumn{6}{|c|}{ Otwartość na zmiany } \\
\hline $\begin{array}{l}\text { Znajomość wartości odżywczej wpłynę- } \\
\text { łaby na mój wybór dania }\end{array}$ & 3,70 & 3,74 & 3,64 & 0,643 & 0,520 \\
\hline $\begin{array}{l}\text { Kiedy idę do McDonald's wiem, co chcę } \\
\text { zamówić i ewentualna informacja żywie- } \\
\text { niowa na temat wybranej przeze mnie } \\
\text { potrawy udzielona mi przez obsługę nie } \\
\text { jest w stanie zmienić mojej decyzji }\end{array}$ & 3,64 & 3,63 & 3,65 & $-0,370$ & 0,712 \\
\hline $\begin{array}{l}\text { Chciałabym/chciałbym mieć możliwość } \\
\text { zapytania personelu McDonald's o in- } \\
\text { formację żywieniową podczas składania } \\
\text { zamówienia }\end{array}$ & 3,53 & 3,62 & 3,43 & 1,450 & 0,149 \\
\hline $\begin{array}{l}\text { Negatywnie oceniam sytuację, w której } \\
\text { personel McDonald's podczas składa- } \\
\text { nia zamówienia udzieliłby mi informacji } \\
\text { na temat wartości odżywczej wybranej } \\
\text { przeze mnie potrawy }\end{array}$ & 3,06 & 3,14 & 2,968 & 1,290 & 0,199 \\
\hline $\begin{array}{l}\text { Negatywnie odebrałabym/odebrałbym } \\
\text { sytuację, w której personel McDonald's } \\
\text { proponowałby zmianę potrawy wybranej } \\
\text { przeze mnie z menu na mniej kaloryczną }\end{array}$ & 3,57 & 3,65 & 3,489 & 0,985 & 0,325 \\
\hline
\end{tabular}

$\mathrm{N}=403$, ${ }^{*}$ test różnic U Manna-Whitneya między grupami względem płci

${ }^{* *} \mathrm{P}<0,05$

Źródło: Badania własne. 
Tabela 3

Zgodność respondentów ze stwierdzeniami dotyczącymi restauracji McDonald's ze względu na płeć

\begin{tabular}{|c|c|c|c|c|c|}
\hline Wyszczególnienie & Ogółem & Kobiety & Mężczyźni & $Z_{\text {pop }}{ }^{*}$ & $\mathrm{P}^{* *}$ \\
\hline 1 & 2 & 3 & 4 & 5 & 6 \\
\hline \multicolumn{6}{|c|}{ Ocena rzeczywistej sytuacji } \\
\hline $\begin{array}{l}\text { Lubię kiedy proces składania zamówie- } \\
\text { nia w McDonald's przebiega szybko } \\
\text { i sprawnie }\end{array}$ & 4,13 & 4,19 & 4,06 & 1,836 & 0,066 \\
\hline $\begin{array}{l}\text { Proces składania zamówienia w McDo- } \\
\text { nald's jest schematyczny i powtarzalny }\end{array}$ & 4,06 & 4,15 & 3,95 & 1,930 & 0,054 \\
\hline $\begin{array}{l}\text { Jestem zainteresowana/y informacją } \\
\text { żywieniowa dotycząca potraw w McDo- } \\
\text { nald's }\end{array}$ & 3,82 & 4,03 & 3,60 & 4,355 & 0,000 \\
\hline $\begin{array}{l}\text { Personel pierwszego kontaktu nie ma } \\
\text { wiedzy na temat wartości odżywczej } \\
\text { potraw oferowanych w McDonald's }\end{array}$ & 3,57 & 3,59 & 3,56 & 0,393 & 0,694 \\
\hline $\begin{array}{l}\text { Nie lubię kiedy personel w McDonald's } \\
\text { udziela mi informacji niezwiązanych } \\
\text { z zamówieniem (np. promocje) }\end{array}$ & 3,36 & 3,40 & 3,32 & 0,774 & 0,439 \\
\hline \multicolumn{6}{|c|}{ Otwartość na zmiany } \\
\hline $\begin{array}{l}\text { Znajomość wartości odżywczej wpłynęła- } \\
\text { by na mój wybór dania }\end{array}$ & 3,70 & 3,82 & 3,57 & 2,316 & 0,021 \\
\hline $\begin{array}{l}\text { Kiedy idę do McDonald's wiem, co chcę } \\
\text { zamówić i ewentualna informacja żywie- } \\
\text { niowa na temat wybranej przeze mnie } \\
\text { potrawy udzielona mi przez obsługę nie } \\
\text { jest w stanie zmienić mojej decyzji }\end{array}$ & 3,640 & 3,522 & 3,763 & $-1,920$ & 0,055 \\
\hline $\begin{array}{l}\text { Chciałabym/chciałbym mieć możliwość } \\
\text { zapytania personelu McDonald’s } \\
\text { o informację żywieniową podczas } \\
\text { składania zamówienia }\end{array}$ & 3,53 & 3,64 & 3,41 & 2,109 & 0,035 \\
\hline $\begin{array}{l}\text { Negatywnie oceniam sytuację, w której } \\
\text { personel McDonald's podczas składania } \\
\text { zamówienia udzieliłby mi informacji na } \\
\text { temat wartości odżywczej wybranej prze- } \\
\text { ze mnie potrawy }\end{array}$ & 3,06 & 3,00 & 3,17 & $-1,098$ & 0,272 \\
\hline $\begin{array}{l}\text { Negatywnie odebrałabym/odebrałbym } \\
\text { sytuację, w której personel McDonald's } \\
\text { proponowałby zmianę potrawy wybranej } \\
\text { przeze mnie z menu na mniej kaloryczną }\end{array}$ & 3,57 & 3,56 & 3,59 & 0,161 & 0,872 \\
\hline
\end{tabular}

$\mathrm{N}=403$, *test różnic U Manna-Whitneya między grupami względem płci

**P $<0,05$

Źródło: Badania własne. 
informacją żywieniową dotyczącą potraw w McDonald's") oraz dotyczącą otwartości na zmiany („Chciałabym/chciałbym mieć możliwość zapytania personelu McDonald's o informację żywieniową podczas składania zamówienia"). W przypadku obu stwierdzeń kobiety zgodziły się w większym stopniu niż mężczyźni.

Ocenę wpływu poszczególnych cech wyglądu personelu restauracji McDonald's na wiarygodność informacji żywieniowej przez niego udzielanej przeprowadzono z wykorzystaniem metody dyferencjału semantycznego (tab. 4, 5).

\section{Tabela 4}

Ocena wpływu poszczególnych cech wyglądu personelu restauracji McDonald's na wiarygodność przekazywanej informacji żywieniowej ze względu na płeć respondentów

\begin{tabular}{|l|c|c|c|c|c|}
\hline Wyszczególnienie & Ogółem & Kobiety & Mężczyźni & $Z_{\text {pop }}{ }^{*}$ & $P^{* *}$ \\
\hline Osoba z niedowaga/osoba z nadwaga & 3,49 & 3,42 & 3,55 & $-1,160$ & 0,246 \\
\hline $\begin{array}{l}\text { Osoba atrakcyjna fizycznie/osoba } \\
\text { nieatrakcyjna fizycznie }\end{array}$ & 3,04 & 3,06 & 3,03 & 0,174 & 0,862 \\
\hline $\begin{array}{l}\text { Osoba bardzo schludna/osoba } \\
\text { nieschludna }\end{array}$ & 2,54 & 2,34 & 2,74 & $-2,952$ & 0,003 \\
\hline $\begin{array}{l}\text { Osoba szybko mówiąca/osoba } \\
\text { wolno mówiąca }\end{array}$ & 3,39 & 3,3 & 3,45 & $-0,953$ & 0,340 \\
\hline $\begin{array}{l}\text { Osoba o wysokim głosie/osoba } \\
\text { o niskim głosie }\end{array}$ & 3,43 & 3,43 & 3,43 & 0,022 & 0,982 \\
\hline Osoba niska/osoba wysoka & 3,39 & 3,34 & 3,43 & $-0,671$ & 0,502 \\
\hline Osoba uśmiechnięta/osoba poważna & 2,47 & 2,38 & 2,57 & $-1,687$ & 0,092 \\
\hline $\begin{array}{l}\text { Osoba o jasnych włosach/osoba } \\
\text { o ciemnych włosach }\end{array}$ & 3,40 & 3,36 & 3,44 & $-0,690$ & 0,490 \\
\hline $\begin{array}{l}\text { Osoba o naturalnym wyglądzie/osoba } \\
\text { o mocno wystylizowanym wyglądzie }\end{array}$ & 2,58 & 2,51 & 2,65 & $-1,040$ & 0,299 \\
\hline
\end{tabular}

$\mathrm{N}=403$, *test różnic $U$ Manna-Whitneya między grupami względem płci

${ }^{* *} \mathrm{P}<0,05$

Źródło: Badania własne.

Opinie respondentów dotyczące wiarygodności informacji żywieniowej przekazywanej przez personel w zależności od jego wyglądu oceniono pod względem wieku badanych oraz faktu posiadania przez nich dzieci. Opinie dotyczące masy ciała, atrakcyjności fizycznej, tempa mówienia, koloru włosów, wzrostu i wysokości głosu personelu okazały się obojętne, można przyjąć, że są to cechy niewpływające na wiarygodność udzielanej przez niego informacji żywieniowych. Średnie dla poszczególnych cech wyglądu kształtowały się na 


\section{Tabela 5}

Ocena wpływu poszczególnych cech wygląu personelu restauracji McDonald's na wiarygodność przekazywanej informacji żywieniowej w zależności od posiadania dzieci przez respondentów

\begin{tabular}{|l|c|c|c|c|c|}
\hline Wyszczególnienie & Ogółem & Z dziećmi & Bez dzieci & $Z_{\text {pop }}{ }^{*}$ & $P^{* *}$ \\
\hline $\begin{array}{l}\text { Osoba z niedowaga/osoba } \\
\text { z nadwagą }\end{array}$ & 3,49 & 3,53 & 3,44 & 0,868 & 0,386 \\
\hline $\begin{array}{l}\text { Osoba atrakcyjna fizycznie/osoba } \\
\text { nieatrakcyjna fizycznie }\end{array}$ & 3,04 & 2,98 & 3,11 & $-0,904$ & 0,366 \\
\hline $\begin{array}{l}\text { Osoba bardzo schludna/osoba } \\
\text { nieschludna }\end{array}$ & 2,54 & 2,4657 & 2,62 & $-0,760$ & 0,447 \\
\hline $\begin{array}{l}\text { Osoba szybko mówiąca/osoba } \\
\text { wolno mówiąca }\end{array}$ & 3,39 & 3,40 & 3,38 & 0,227 & 0,821 \\
\hline $\begin{array}{l}\text { Osoba o wysokim głosie/osoba } \\
\text { o niskim głosie }\end{array}$ & 3,43 & 3,30 & 3,59 & $-2,172$ & 0,030 \\
\hline Osoba niska/osoba wysoka & 3,39 & 3,40 & 3,38 & 0,140 & 0,889 \\
\hline Osoba uśmiechnięta/osoba poważna & 2,47 & 2,48 & 2,46 & 0,022 & 0,982 \\
\hline $\begin{array}{l}\text { Osoba o jasnych włosach/osoba } \\
\text { o ciemnych włosach }\end{array}$ & 3,40 & 3,42 & 3,38 & 0,370 & 0,711 \\
\hline $\begin{array}{l}\text { Osoba o naturalnym wyglądzie/ } \\
\text { losoba o mocno wystylizowanym } \\
\text { wyglądzie }\end{array}$ & 2,58 & 2,53 & 2,64 & $-0,779$ & 0,436 \\
\hline
\end{tabular}

$\mathrm{N}=403$, "test różnic U Manna-Whitneya między grupami względem posiadania dzieci

${ }^{* *} \mathrm{P}<0,05$

Źródło: Badania własne.

poziomie dla: masy ciała - 3,486, atrakcyjności fizycznej - 3,042, tempa mówienia - 3,392, koloru włosów - 3,402, wzrostu - 3,387, wysokości głosu - 3,434. Różnice w wynikach dla cechy dotyczącej wyglądu osobistego określonego jako osoba bardzo schludna lub nieschludna między grupami były istotne statystycznie. Średnia z odpowiedzi kobiet wyniosła 2,337, a z odpowiedzi mężczyzn $-2,742$.

Cechy personelu takie jak uśmiech, schludność i naturalny wygląd wpływają pozytywnie na wiarygodność udzielanej przez niego informacji żywieniowej. Średnie z odpowiedzi kształtowały się na poziomach: 2,536 dla osoby schludnej, 2,471 dla osoby uśmiechniętej, 2,578 dla cechującej się naturalnym wyglądem. Różnice w postrzeganiu cechy dotyczącej wysokości głosu między grupami osób mających dzieci i bezdzietnych były istotne statystycznie, średnia z odpowiedzi osób mających dzieci wyniosła 3,304, a w przypadku osób bezdzietnych 3,586. 


\section{Wnioski}

Bezpośredni kontakt z klientem jest jednym z ważnych czynników społecznych determinujących zachowania konsumentów w zakładach gastronomicznych. Ten aspekt nabiera szczególnego znaczenia w kontekście nowych trendów w zakresie żywności i żywienia takich jak serwicyzacja konsumpcji. Dodatkowym zagadnieniem jest wpływ personelu na kształtowanie postaw i zachowań konsumentów w sferze usług przy znaczącym udziale uwarunkowań o charakterze niematerialnym. W tym obszarze należy analizować m.in. składanie zamówień, udzielanie informacji i realizację zamówienia. Konieczne jest zwrócenie uwagi na elementy wpływające na percepcję przekazywanej informacji, w tym informacji o charakterze żywnościowym przez personel pierwszego kontaktu. Determinuje to postrzeganie otrzymanej przez konsumentów informacji żywieniowej pod względem wiarygodności, stanowiąc podstawę podjęcia określonej decyzji zakupowej. Jednocześnie wpływa na ocenę rzeczywistej sytuacji, atmosferę w miejscu zakupu i konsumpcji oraz możliwość wprowadzenia zmiany wcześniej dokonanego wyboru.

Takie podejście - odnoszące się do poznania uwarunkowań społecznych w kontekście bezpośrednich relacji z konsumentów - należy traktować jako element zarządzania relacjami i czynnik mogący zwiększyć przewagę konkurencyjną danego przedsiębiorstwa gastronomicznego. Bezpośrednie relacje są podstawą do budowy zaufania konsumentów, w konsekwencji satysfakcji z otrzymanej usługi, co determinuje lojalność konsumentów wobec konkretnego zakładu gastronomicznego działającego pod określoną marką.

\section{Literatura}

ANTONIDES G., Van RAAIJ W.F., 2003: Zachowanie konsumenta, PWN, Warszawa.

ENGEL J.F., BLACKWELL R.D., MINIARD P.W., 1993: Consuner Behavior, Dryden Press, Illinois.

FOXALL G.R., GOLDSMITH R.E., 1998: Psychologia konsumenta dla menedżera marketingu, PWN, Warszawa 1998.

GAJEWSKI S., 1997: Zachowania się konsumenta a współczesny marketing, Wydawnictwo Uniwersytetu Łódzkiego, Łódź.

GÓRSKA-WARSEWICZ H., 2013: Konsument jako odbiorca działań marketingowych na rynku żywności $i$ ustug żywieniowych [w:] H. Górska-Warsewicz, K. Krajewski, M. Świątkowska (red.), Marketing żywności, Wolters Kluwer, Warszawa.

GRABOWSKA J., 2013: Analiza procesu obstugi klienta na przykładzie przedsiębiorstwa górniczego, Zeszyty Naukowe Politechniki Śląskiej. Organizacja i Zarządzanie 63. 
GUTKOWSKA K., OZIMEK I., 2005: Wybrane aspekty zachowań konsumentów na rynku żywności - kryteria zróżnicowania, Wydawnictwo SGGW, Warszawa.

JACHNIS A., 2007: Psychologia konsumenta. Psychologiczne i socjologiczne uwarunkowania zachowań konsumenckich, Oficyna Wydawnicza „Branta”, Bydgoszcz - Warszawa.

KRAMARZ M., 2014: Elementy logistyczne obstugi klienta w sieciach dystrybucji. Pomiar, ocena, strategie, Difin, Warszawa.

KRAMER J., 1997: Konsumpcja w gospodarce rynkowej, PWE, Warszawa.

MAZUREK-ŁOPACIŃSKA K., 2003: Zachowania nabywców i ich konsekwencje marketingowe, PWE, Warszawa.

PAYNE A., 1997: Marketing ustug, PWE, Warszawa.

POHORILLE M., 1980: Mechanizmy i kierunki zmian w konsumpcji społeczeństwa polskiego, [w:] Systemy wartości a wzory konsumpcji społeczeństwa polskiego, Instytut Socjologii UW, Warszawa, 490.

RUDNICKI L., 2012: Zachowania konsumentów na rynku, PWE, Warszawa.

SZCZEPAŃSKI J., 1976: Wydajność pracy a konsumpcja, Nowe Drogi 11.

ŚWIATOWY G., 2006: Zachowania konsumentów, PWE, Warszawa.

\section{Abstrakt}

Celem opracowania była ocena percepcji informacji żywieniowej przekazywanej przez personel pierwszego kontaktu jako element wpływający na zachowania konsumentów w zakładach gastronomicznych. Badania przeprowadzono w ramach projektu naukowo-edukacyjnego „Konsument na rynku usług gastronomicznych", nr 507-30-102-M00094-99, realizowanego w Zakładzie Zarządzania w Gastronomii i Hotelarstwie na Wydziale Nauk o Żywieniu Człowieka i Konsumpcji SGGW. Badanie ilościowe na próbie 403 osób z wykorzystaniem doboru celowego przeprowadzono w czerwcu 2016 roku. Przyjęto kryteria wiek (od 18 do 35 lat), zamieszkiwanie w dużych miastach oraz fakt korzystania $\mathrm{z}$ usług lokali gastronomicznych.

Słowa kluczowe: informacja żywieniowa, personel pierwszego kontaktu, zachowania konsumentów

\section{Evaluation of nutritional information as an element influencing consumer behavior in gastronomy services}

\section{Abstract}

The aim of this study was the evaluation of nutritional information provided by frontline staff as an element influencing consumer behavior in gastronomy services. The empirical research was conducted under the project "The consumer 


\section{6}

in the market of catering services", number 507-30-102-M00094-99, realized in the Chair of Gastronomy and Hospitality Management in the Faculty of Human Nutrition and Consumer Sciences at the Warsaw University of Life Sciences - SGGW. Quantitative research on the sample of 403 persons using purposive sampling were conducted in June 2016. The criteria of age (18-35), living in large cities as well as the fact of eating out.

Key words: nutritional information, frontline staff, consumer behavior 